This article was downloaded by: [Goldsmiths, University of London]

On: 17 October 2011, At: 08: 16

Publisher: Routledge

Informa Ltd Registered in England and Wales Registered Number: 1072954

Registered office: Mortimer House, 37-41 Mortimer Street, London W1T 3J H, UK

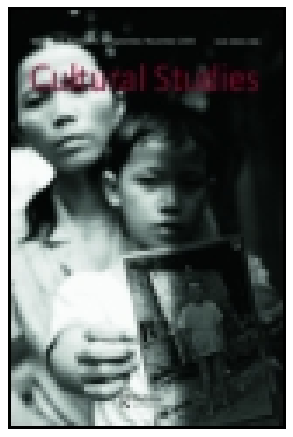

\title{
Cultural Studies
}

Publication details, including instructions for authors and subscription information:

http:/ / www. tandfonline.com/loi/ rcus20

\section{YOUNG WOMEN AND CONSUMER CULTURE}

Angela McRobbie

Available online: 21 Aug 2008

To cite this article: Angela McRobbie (2008): YOUNG WOMEN AND CONSUMER CULTURE, Cultural Studies, 22:5, 531-550

To link to this article: http:/ / dx.doi.org/ 10.1080/ 09502380802245803

\section{PLEASE SCROLL DOWN FOR ARTICLE}

Full terms and conditions of use: http://www.tandfonline.com/page/termsand-conditions

This article may be used for research, teaching, and private study purposes. Any substantial or systematic reproduction, redistribution, reselling, loan, sublicensing, systematic supply, or distribution in any form to anyone is expressly forbidden.

The publisher does not give any warranty express or implied or make any representation that the contents will be complete or accurate or up to date. The accuracy of any instructions, formulae, and drug doses should be independently verified with primary sources. The publisher shall not be liable for any loss, actions, claims, proceedings, demand, or costs or damages whatsoever or howsoever caused arising directly or indirectly in connection with or arising out of the use of this material. 


\section{Angela McRobbie}

\section{YOUNG WOMEN AND CONSUMER CULTURE}

\section{An intervention}

This article is presented as an intervention in the field of feminist media and cultural studies with particular reference to consumer culture. It is concerned with the seeming evasion of critique which can be detected in a number of recent feminist responses to the way in which modalities of 'popular feminism' have found themselves incorporated into women's genres of television, such as, in particular, the US series Sex in the City. This usage or instrumentalization of feminism (in its most conventionally liberal feminist guise) also provides corporate culture with the means of presenting itself to young women as their ally and even champion of 'girls' while at the same time earning seeming approval for adopting the mantle of social responsibility, which makes the concept of popular feminism more problematic than it first appeared. Such appropriation of popular feminist discourse by the commercial domain prompts a self-critique on the part of the author alongside an analysis of recent approaches toward consumer culture in cultural studies. The article continues by presenting a schematic account of how the commercial domain increasingly supplants state and public sector institutions in the intensity and dedication of its address to girls and young women. Whilst some may argue that the intersection of youthful femininity and the commercial sphere is not a new phenomenon, what is being explored here is the connection between this intensification of attention and the logic of current neo-liberal economic rationalities. The argument is, therefore, that it is by these means including the instrumentalization of a specific modality of 'feminism' that there emerges into existence a neo-liberal culture, with global aspirations, which has as its ideal subject the category of 'girl'.

Keywords commodity feminism; consumer culture; gendered individualization; post-feminism; popular culture; self-critique 
What I can be quite literally is constrained in advance by a regime of truth which decides in advance what will and will not be a recognisable form of being ... this does not mean that a given regime of truth sets the invariable framework for recognition: it means only that it is in relation to this framework that recognition takes place or the norms that govern recognition are challenged or transformed.

(Butler 2005)

\section{The perils of 'commodity feminism'}

This paper is intended as an intervention. It is presented as a series of interconnecting notes on a range of topics which include: (a) consumer culture as a regime of truth and its problematic status within feminist media and cultural studies; (b) the recent, extraordinary, prominence of young women in consumer culture; (c) the making and shaping of new markets for very young girls; (d) the encroachment by commercial forces on the role and authority of the various institutions which have, in the past, presided over the lives and conduct of young women and girls. We might say, in regard to this last point, that the old social institutions of family, education, medicine and law, which have historically been charged with the responsibility of producing and reproducing the category of girl as a certain kind of subject, and thus with ensuring that appropriate processes of sexual differentiation take place, have seen their responsibility eroded in recent years. One normalizing process is being replaced now by another. Consumer culture, riding the wave of UK governmental off-loading of social responsibility through de-regulationist policies, has grabbed hold of this terrain, turning it into the most profitable of opportunities. Of course there has been a long history of commercial culture (in both instructional and pleasurable modes) directing itself towards the site of girlhood. However, my claim here is that this force is now accelerated and expanded with the effect that commercial values now occupy a critical place in the formation of the categories of youthful femininity. This appropriation of the site of girlhood actively draws on a quasi-feminist vocabulary which celebrates female freedom and gender equality. The effects of this shift have not, as yet, been fully recognized within feminist writing, although there have been a number of articles which grapple with the remarkable growth of popular culture (fashion, beauty, music, magazines, etc) and its increasing focus towards pre-teenage as well as older girls. It has also been acknowledged that many of the forms directed towards girls and young women seem to have embraced what has been troublesomely labelled 'popular feminism'.

Feminist scholars have tended to see this in fairly positive terms. However, this favourable response is something I now want to query. It has been my 
contention elsewhere that the process of taking feminism into account is a complex strategy, one which can actually have the effect of 'undoing' feminism, and of actively discouraging its renewal (McRobbie 2004). Popular feminism is celebrated in such a way as to suggest that the politics of feminist struggles are no longer needed. Seemingly supplanting feminism per se, and appearing to adopt the interests of girls and young women, commercial culture finds a licence to speak on their behalf. Companies draw on the language of 'Girl Power' as though to bestow on their products a sense of dynamism, modernity and innovation. Such post-feminist strategies allow for the expansion of the 'teen girl' global market on the basis of re-invention of the category of youthful womanhood, for whom freedom has now been won; or, in the case of developing countries, is in the process of being won. I want to suggest that this popular feminist appropriation permits more subtle modalities of gender reinscription and re-subordination to be pursued. This intensity of commercial interest in young women, accompanied by the generation of vast quantities of research data which seek to produce the girl as a knowable subject, also coincides with an emergent style of 'joined-up' governmentality on the part of New Labour in the UK which seeks to re-define female citizenship in directions contrary to those of public-mindedness, political participation, democratic accountability, social welfare and what used to be known (albeit problematically) as the feminist ethic of care. My claim here is that this convergence of commerce and government has quite fatal consequences requiring renewed feminist attention, including an element of feminist (self) critique. This article is divided into three sections. First, I provide an account of feminist responses to consumer culture, which allows me to reflect critically on some of my own previous contributions to this debate. Second, I present a response to recent feminist writing on the US television series Sex in the City, which in turn leads me to comment on the forms of compulsory consumption which this and other programmes so fully endorsed. I also draw attention to consequences of the avoidance of theory, particularly psychoanalytic feminist theory, in much of this work. And third, I consider how very young girls (i.e. children) are now also being drawn into participating in these same practices as a requirement of normative post-feminist femininity.

\section{Feminism and consumer culture}

Within the last decade a substantial sector of the commercial domain has embraced notions of gender equality ('the pretence of equality' as Jean-Luc Nancy would have it) and has used this ideal as a means of generating and disseminating more energetic, confident and assertive accounts of girlhood and young womanhood (Jean-Luc Nancy 2000). This process can be seen in the fields of popular music, girls' and women's magazines, cinema, television and 
advertising. My focus of attention here is primarily on television and magazines, although, of course, increasingly, in a multi-media world, all of the above forms intersect with each other in various ways. Television is possibly the most powerful of these media, and it has been feminist television studies which has most thoroughly responded to these changes. The publication of Dow's Prime-Time Feminism (1996), followed by Brunsdon et al. Feminist Television Criticism (1997) have provided a vocabulary which has then been drawn on by a new generation of feminist scholars to examine programmes such as Ally McBeal and Sex in the City, and, for younger girls, As Told by Ginger and Clarissa Explains It All (Dow 1996, Lotz 2001, Moseley \& Read 2002, Banet-Weiser 2004, Tasker \& Negra 2006). These programmes have emerged at a time when young women in Western societies are gaining better educational qualifications, are entering the labour market in unprecedented numbers and, instead of leaving the workplace with the onset of motherhood, are delaying maternity, avoiding it altogether, or else are returning to work not long after childbirth. This emphasis among young women on wage-earning capacity, along with changes in sexual status and maternity, is also an increasingly global trend. And in the affluent West it offers great opportunities for new forms and patterns of consumption.

While these issues have been discussed by feminist social scientists, in feminist media and cultural studies they tend to be only acknowledged rather than drawn on as starting points for analysis. At best, they are recognized as playing a role in the kinds of television programmes which are made, or newspapers and magazines which are produced, since there is now a substantial female audience and readership with a disposable income. These factors have been credited with contributing to the feminization of television and the lifestyling of the national press. Women's and girls' magazines have always been seen as providing windows of opportunity for consumption, but the extraordinary increase in this focus on goods and products has tended to go relatively unnoticed in recent feminist writing. Instead of focusing on these issues, feminist media scholars have been drawn to questions of feminine pleasures. And because aspects of feminism have found their way into the narrative content, these pleasures are now deemed less problematic - even, seemingly, delightful. On this basis feminist scholars are now less hesitant about describing themselves as fans than was previously the case. I see this as a troubling development. This approach to pleasure emerges, not out of a complex psychoanalytic feminism which would point to its deeply ambivalent status, and to desire as unruly and chaotic, but instead through an argument in cultural studies, now otherwise redundant, that pleasurable readings of popular texts can mark out moments of audience empowerment and subversive identity formation. Although, as will become apparent later, my own work on young women's magazines has tended to pursue a slightly different course from that of feminist television studies, many of the points of 
self-critique which I make here can also be applied to aspects of the television work. Without being, I hope, and despite McGuigan's (1992) claims to the contrary, a proponent of the kind of 'cultural populism' which attributes subversive features to forms of popular immersion in mainstream cultural forms, I am willing to portray myself here as a key offender in rushing too quickly to welcome the ways in which the young women's magazine sector took on board a range of issues which had been of key importance to a previous generation of feminist scholars and activities. The failure to interrogate the conditions upon which such an embracing of seeming female freedoms was predicated by media organizations meant that the relations of power underpinning and overseeing such a move remained worryingly invisible.

Through the 1990s I found myself returning to the girl's magazine as a cultural phenomenon (McRobbie 1999). It was apparent that there had indeed been some major editorial shifts, seemingly influenced by feminist debate. In the mid-1970s I had argued that these cultural forms perpetrated acts of symbolic violence against young female readers by casting them as passive, conformist, willing subjects of romantic ideology, easily persuaded by the various seductions of advertising and consumption, on the basis of a pervasive insecurity which these forms actively invoked. Looking back at this work now, from within its own terms, where the omnipotent power of media and consumer culture was understood to be manifest in a solicitous cajoling and intimate address, I am reminded of the centrality of Marxist thought on that era of scholarship. The emphasis on the sameness of these forms, with their concerns formulaically repeated on a weekly basis; the constant focus on femininity as requiring the regular consumption of products for fear of repudiation by others, the production of the normative, unquestioning and quiescent female subject by means of the commodity form (the magazine itself, as well as the many products it advertised and promoted), show the impact of Althusser's landmark essay on ideology and reproduction (Althusser 1971). In the years that followed, instead of pursuing a more Foucauldian approach which would have sustained the interest in power, but without the doctrinaire underpinning of the Althusserian theory of ideology, and which would have been highly attentive to the conditionality upon which any definition of female freedom might be based, the tendency in feminist media and cultural studies was to look instead in the direction of audience and reception studies.

This approach, on the basis of its interest in practices of everyday life, on ordinary people, on the housewife, and on the ordinary girl or woman, also had a Marxist heritage. From the 1950s until his death in 1969 Adorno and his Frankfurt School colleagues had developed a Marxist theory of culture which, by means of negative dialectics, sought to expose the contradictions which inhered within the divide between high art and low culture, and which endeavoured through a principle of non-identity to contrive a re-functioning of art so that it could retain and develop in an unresolved and open-ended way its 
revelatory and utopian capacity. This perspective neither allocated any principle role for the working class in bringing about social transformation (so pacified was this class by the culture industry), nor did it endorse the leadership role of the radical intellectual (for fear of Party dogmatism). Without endorsing a leadership role for radical intellectuals, British Marxistinfluenced cultural studies, formed almost at the moment of Adorno's death, nevertheless turned this on its heels and sought to find ways of engaging with popular forms and practices associated with working-class organizations and then later with women, with black people, youth and so on, under the influence of Gramsci's model of the organic intellectual and his analysis of popular forms as marking out potential sites of struggle. There was then a stretching out to the people, implicit and explicit, in Gramsci's work, with particular place given to pedagogy. In the now classic works emerging from the Birmingham school there were a range of objectives, all contrary to the Adorno position. First, to examine popular cultural forms without the assumption that because they were the products of a capitalist commodity system their meaning was entirely conformist and subservient to dominant values; second, to analyse the subordinate social groups (working class, youth, young women, black people, etc.) who, it seemed, had a particular attachment to these so-called 'low' cultural forms and could be studied by drawing on sociological methods including ethnography; thirdly, to envisage these same groups as not entirely outside of the realm of academic debate, but rather to forge some sense of connectedness perhaps through non-standard pedagogies, with the subordinate social groups who were also the objects of academic inquiry; and finally to establish a mode of enquiry which was quite free of judgement of cultural values in the field of taste, and which, in effect, from the start dignified the attachments subordinate peoples had to the activities and practices which Adorno so scornfully described. This approach therefore avoided the moralistic and condemnatory tone in which Adorno wrote. Of course Adorno was venting his anger against the architects of the new mass media and the banal and simplistic meanings which they conveyed to those whose powerless position in work and in general made them vulnerable to the desire for escapism and who were so tired and worn out that simplistic entertainment was also a relief.

The question now to feminist scholars in popular culture is: what might there be to gain from a return to Adorno, especially when there is now such a vast female population of consumers who also, after long hours of paid and unpaid work, find themselves the new ideal subjects of consumer culture? Might it be the case that cultural studies was indeed, too hopeful or even optimistic about the possibilities of radical change which could conceivably take place, both within and outside of commercial institutions? Might there also have been little sense of just how powerful consumer culture could 
become in the lives of women of all ages, which might then lead to a conclusion that in certain respects Adorno was right?

There were two themes I explored in a number of articles written from the mid-1990s. The first was the changed landscape of girls' magazines where it seemed feminist issues had been addressed to some extent, and the second theme related to pedagogical and political issues in the exchange between feminist academics and female students. In contrast to the narrow and restricted coding of femininity in magazines prior to the early 1990s, both myself and Janice Winship noted these changes with some degree of affirmation (McRobbie 1999, Winship 1987). On my own part the decline of cloying romantic narratives and the emergence, albeit in consumerist guise, of a more independent or 'individualized' girl, and then the presence on these pages of a more sexually active young women whose behaviour challenged the old patriarchal double standards which had for so long been a means of policing female sexuality for fear of incurring a bad reputation or, worse still, for being branded 'disreputable', were all grounds for suggesting that these cultural forms had somehow listened to wider feminist debate. In addition there were areas where editorial responsibility extended to making feminist commonsense more widely available to young women readers on issues such as abortion and contraception, racism, sexual health, rape, sexual violence, workplace harassment, and other related issues. Magazines also implemented feminist-informed government guidelines by advocating safe sex and did so in a language which addressed readers in a more effective way than classroom based sex education. If this material sat alongside an endless stream of glossy advertisements for fashion and beauty products, if it meant that lesbian sexuality was still more or less ignored. If there was still virtually no attention to questions of race and ethnicity with predominantly white models still found across the fashion and beauty pages, and if it meant that there was still scant consideration of wider political issues, and no address to young women readers as anything other than narcissistic, pleasure-seeking, individualized and fatally insecure subjects, then it is also the case that I pushed these matters to the side and chose to emphasis instead the scale of the changes.

My interactions with the many young women students whom I taught and who graduated with the intention of looking for work inside these media organizations usually with an aim of bringing a popular feminist agenda to bear within the magazines, led me, in the spirit of feminist affirmation, to downplay the obstacles which thwart such changes (e.g. advertising revenue) and to be less attentive to the capacity within such media forms for transforming progressive principles into new forms of constraint. ${ }^{2}$ This stance also challenged elements of feminist dogmatism which had long adopted a censorious attitude to commercially-defined femininity, as well as to the more aggressive and spiky femininities of punk, and the various subcultural styles which have followed on from punk. And while feminist film theory did 
indeed produce exceptionally important work on femininity as masquerade, feminist media and cultural studies tended to pursue a distinctively nonpsychoanalytical pathway. By the early 1990s, with feminist scholarship ensconced within the academic curriculum, and thus itself having accrued degrees of power and authority, expressions of disaffection from elements of now-canonized academic feminism on the part of female students, did not, to me, suggest the repudiation of feminism per se by younger women. Instead, both myself and Charlotte Brunsdon sought to understand the processes of, and disruptions to, feminist reproduction inside the academy as productive (Brunsdon 1997, McRobbie 1999).

However it is now apparent that these complex social relations within the university as an academic institution and also in the media field, require much more careful consideration than these various commentaries provided. My writing was inattentive to those elements of patriarchal power or the heterosexual matrix (e.g. female anxieties about the body, the need for male approval, the search for a husband) which saw this power augmented and consolidated rather than reduced during this time, and was in fact quickly able to exploit, and duly benefit from, the emerging post-feminist language of personal choice, freedom and independence which the magazines of the 1990s endorsed. Likewise the emerging codes of sexual freedom and hedonism ought to have been understood as manifestations of new technologies of the self which once again secured the youthful female subject in designated ways according to a limited (or expansive) range of legitimate desires and pleasures. In addition more attention should have been paid to the requirements imposed on editors, in spite of any feminist ethos they might profess, by the role of advertising revenue and the constant need to increase circulations for the multinational publishing companies as a condition of employment. This last factor would also have permitted greater awareness of shifts and swings in editorial policy, such that a magazine might indeed have a period during which it does take up a more challenging stance, only for this to be reversed some months later in the light of falling sales or declining advertising copy. ${ }^{3}$ My own writing at this point was also inattentive to the normative production and reproduction of white, heterosexual identities so that despite social changes and liberalization in regard to gay and lesbian sexualities - and indeed on the basis of such changes having taken place - boundaries were all the more firmly and defensively marked out and lesbian young women implicitly invoked as contrary in personal style and appearance to all that counted as intelligible for the achievement of successful or effective girlhood. Thus the brutality of racial and sexual exclusion was also relatively absent from my responses to changes within the landscape of magazines and consumer culture through the 1990s. Underpinning my naïve hopefulness about potential for editorial change from within these publications was an extension of the Gramscian model of the organic intellectual now transposed by means of feminist pedagogy into 
advocating 'popular feminist' practice within commercial organizations. (What should have been addressed was the discrepancy in this respect between the pursuit of radical politics inside public sector institutions, and the unlikely possibility of this within the commercial sphere.) This left unconsidered the great yawning gap between the status of feminist scholarship within the academy, and its translation (not to say its distortions) into the social and cultural world.

\section{Feminism and Sex in the City}

The television series Sex in the City exemplifies many of these consumerist trends, noted earlier, having perfected for television a style of programming which easily translates the conventional interests of the women's glossy magazine directly into the format of a drama series. Indeed the seemingly sensational or shocking contents of the television programme are in fact the staple of women's magazine contents, and it is only when the intimacy of the magazine address crosses over into the more public world of television that the question of shock arises. Sex in the City has been the programme which has given rise most forcefully to the idea of complicitous critique, ${ }^{4}$ a (in my mind deeply problematic) style of scholarship which examines cultural phenomena from a feminist perspective, but which appears to suspend critical engagement with the wider political and economic conditions which shape the very existence, as well as the circulation and availability, of these forms. I shall return to this point later, but for the moment I wish to query the political consequences of complicity. Does it, in this particular field, signal what Žižek would call a 'procapitalist' stance? (Žižek 2004). Has there been a move away from the affirmation of radical democratic values in some recent feminist scholarship in the field of media and cultural studies, and, if so, where does this leave the mode of feminism that is being endorsed? What does the term 'complicitous critique' have to say about critique itself, its degree of ferocity or mildness? Has radicalism in feminist scholarship declined, and if so what is the political valency of the work which takes its place? Tasker and Negra suggest that just because feminism has proved itself to be translatable into the commodity form, this should not make feminist scholars dismiss 'the development of popular consumer-led versions of feminism as simply more of the old patriarchal same' (Tasker \& Negra 2005). To which I would now add, not simply the old, but rather the new 'patriarchal same'. Indeed it is my claim that there is now, embedded within these forms of feminine popular culture, a tidal wave of invidious insurgent patriarchalism which is hidden beneath the celebrations of female freedom. In addition to ignore the consequences of commodity feminism is to abandon the terrain of understanding young women's position in the contemporary social order and the 
instrumentalization of feminism. In many of the works cited later, feminist authors and editors alike proclaim themselves, unashamedly, as fans of Sex in the City. This extends to (with some degree of self-consciousness and academic gesturing to others who do the same) declaring 'love' for specific characters and for their lifestyle (Jermyn 2004). Fandom then seems to be the key to understanding complicity. But in this context and in the absence of a prior, or old-fashioned feminist vocabulary which was concerned with the power of these media forms, and their role in producing sexual objectification, differentiation and subordination, the role of critic is, under the circumstances, somewhat attenuated. Instead there is a good deal of description of individual episodes and other information, most of which is, in fact, already available on the internet. In what is surely a friendly academic endorsement for Sex in the City, Akass and McCabe re-print a recipe for a cocktail drink in the frontispiece and include, at the end of the book a full guide with map to the shops, bars and restaurants which are frequented by the four characters in the programme (Akass \& McCabe 2005). And one article in this volume describes in a factual tone how the programme was used in the months following the events of $9 / 11$ to revitalize New York's flagging tourist economy. The four characters participated, it seems, in patriotic shopping, as a mark of their exemplary female citizenship. Zeiger uses the term 'sexual citizenship' (which has been part of an important set of theoretical discussions by various scholars including Lauren Berlant, Jeffrey Weeks and others) but with no critical purchase whatsoever. Nor does she offer any interrogation of the editorial decisions to include, in a post 9/11 episode, a narrative which presented Samantha's hyperactive sexual desire as patriotic, on the basis of it being aroused by the pleasing sight of men in uniform (Zeiger 2004). It seems here that as Adorno once said 'critical thinking is threatened with extermination' (Adorno 1991).

In addition, where it might be expected that, in the context of white, affluent single women in well paid jobs in New York, the limits of the liberal feminism which inform some of their attitudes and preferences might be fully engaged with, this is not the case. Instead, there are references in passing to Miranda temporarily dating a black doctor. This episode, full of underpinnings of frisson and white female daringness, surely warrants in-depth critical analysis, if anything like an anti-racist feminist scholarship is to be directed to this programme. The same could be said about Samantha's attempt at a lesbian relationship which somehow invoked, by the end of the short affair, a heterosexual shudder, a kind of distaste and relief at returning to normality. ${ }^{5}$ Only Mandy Merck contextualizes these characters as exemplifying an aspirational, and in one case preppy, conservative, white, middle-class femininity for whom liberal feminism has brought some not entirely welcome advantages (Merck 2004). Jane Arthurs draws on Lash's account of mobile subjectivities emerging from the montage style of incessant media imagery associated with consumer culture to make a case for the female characters in 
Sex in the City (and implicitly their audience) as located within an aspirational, liberal-minded, middle class (Arthurs 2004). This also marks one of the few moments of wider contextualization, and Arthurs argues that this sensibility, with its interest in self-aestheticization, accounts for the ironic knowingness, not to say guilty pleasures, of consumption indulged in by the characters in the series, particularly Carrie. Yet it could just as easily be argued that, following the lead from glossy fashion magazines, the show creates and manages a more rampant, insatiable and quite unreflexive world of consumption by precisely drawing together and showcasing a vast range of diverse consumption practices, from luxury top range items, to the seeking out of second-hand dresses and vintage clothes. No stone is unturned in the endless search for new treasures. And self-reflexivity goes no further than a mildly self-mocking personal reprimand when this enjoyable habit threatens to get out of control. Thus the programme, as Miller and Rose (1997) would put it, mobilizes the consumer, creating an ethos of unlimited consumption which requires particular technologies of self, of which constant self-monitoring is but one element. Within this framework it is the multi-layered structure of consumption practices intersecting with the figure of the wage-earning female subject located within the urban environment which produces a distinctively gendered and racialized class positioning by cultural and highly mediated means, rather than the other way round.

None of the earlier authors examines the cloying girlie infantilism of the Carrie Bradshaw figure, whose feminine masquerade (notwithstanding its possibilities for queer readings) surely undercuts any authority she might have as a writer on a reputable newspaper, and acts a means instead of endearing herself to men in a pre-feminist gesture par excellence. This endless masquerade (glancing in the pocket-mirror, touching up her make-up, catching sight of herself in shop windows, doing girlish twirls in front of the full size mirror) on the part of the lead character shows how Sex in the City works as a provocation to second-wave feminism and how it enacts a kind of gender re-stabilization by summoning the ghost of the old disapproving feminist, (did she ever really exist?) only to dismiss her in a flash by over-doing, quite hysterically and fearfully, the comforting rituals of femininity. The 'little girl in need of protection' style of Carrie may be ironically performed as though to suggest knowing distance from traditional and naïve femininity, but irony or feminine performativity in this environment seems to be deliberately deployed (in a 'post-queer theory' gesture) to secure, once again, comforting gender normativity.

The performance of spectacular femininity by the female characters in Sex in the City demands fuller theoretical attention than it has so far received. The way in which the reader is made aware of the artifice of femininity and the labour as well as love invested in these daily performances suggests, but then hastily works to contain and stifle, the kind of possibility for subversion argued 
by Judith Butler (1990). Femininity is always a doing, and the pastiche of drag dramatizes the way in which there is no original, or natural, femininity, it is always a kind of staging. On this basis gender is inevitably unstable, as it owes its existence to these repeated acts which could conceivably fail. It is tempting for feminist critics to see the ritualistic femininity publicly enacted by the four 'girls' as demonstrating gender's instability. First, because so much narrative attention is drawn to its endless and repeated stagings, second, because these requirements are also self-consciously reflected on by the characters, especially Carrie, who, like so many other post-feminist figures, shows herself to be ambivalently aware of feminism as embodying a critique of these high maintenance expectations, and third, because the prominence in the programme of femininity as necessarily spectacular, promotes the idea to the audience that femininity is indeed a kind of drag. Both the girls and their gay male friends share a common understanding of gender's unnatural status. However, far from these factors operating to widen the possibilities of gender difference to permit expansiveness into what it is, or might be, to be a woman, or to explore in a comic vein the sexual politics which might accrue from this realization, such opportunities are foreclosed. The performative here has the effect of seeming to re-instate the 'original'. This re-instatement takes place within the various narrative strands which see the girls explore transgressive sexualities, only to return, chastened, to familiar and knowable heterosexuality. The gender re-stabilization which occurs in Sex in the City is based on the ability of the girls to control the excess of femininity by reconciling it with more normative cultural practices, i.e. shopping and consumption. In this way the girls show themselves to be reassuringly real women. In fact the resolution of these possibly transgressive desires into a straightforward endorsement of the joys of consumption, made possible through the female wage, re-secures a scenario of gender normativity, merely adjusted to take into account the various advantages to the social order which come about through this independent economic activity.

In most feminist responses to the programme, however, we find little in the way of critical analysis of gender retrenchment and the undoing of feminism. Nothing is said about Carrie's desperate child-like search for male approval, or about her schoolgirl voice-overs which introduce each episode. The wooden self-consciousness and painful banality of language reveal the limits of her ambition subordinated as it is to refusing any emotion (such as anger) which would make her even temporarily unappealing to men. Instead there is only tedious narcissism, as she skips down the street wearing an ill-chosen hat and stupendously expensive shoes not made for walking. But, because these four girls with their staged femininity permit any number of (in fact problematic) queer readings, it is assumed that their inhabiting of femininity is somehow subversive and thus relevant to feminism (Gerhard 2005). Mandy Merck (2004) offers a rigorous and persuasive account of the 
gay sensibility which does indeed suffuse the series and its sexual comedy, shaping its frank portrayal of sexual appetite. But does this possibility let the programme off the hook in regard to its pervasive conservatism? Surely not. It does seem to permit, however, the celebratory rhetoric on the part of most feminist critics, and overall affirmation of the programme. What is required perhaps, is an analysis which explores how the manipulation of nonheterosexuality, which underpins the programme in that gay male sex provides a landscape which is culturally compatible through vectors of friendship with these seeming female freedoms. Meanwhile, narrative space is also given over, in a relatively resigned and fatalistic way, to the requirement that real women must submit themselves to the norms of heterosexual femininity for love and sexuality to have meaning and for life to take its rightful course.

There is lack of sustained attention to the narcissistic female subject in Sex in the City and the normative channelling of sexual desire, despite the proliferation of queer readings. But also there is a holding back from confronting the politics of rampant female consumerism. Perhaps the way in which the show functions as a televisual magazine and shop window for the successful launching of shoes, accessories and fashion lines well beyond the means of average female viewers and within reach only on the basis of extended credit cards and borrowing, is too banal a point for feminist media scholars to make, fearful of the charge of economic reductionism. But the common sense knowledge that Sex in the City injected new life into the world of luxury goods and brands in particular key designer lines of shoes, should not, surely, mean that this dimension is of no significance at all. And if, alternately, the point of the show is to pander to female fantasy, once again only Merck explores the terrain of sexuality and desire more substantially. In short, there is an under-theorization going on here, and some unwillingness to return more critically to questions of consumerism. At most there is a flicker of recognition that consumer culture plays a compensatory role for various tensions or disappointments in women's lives. If feminism is seen to inform these texts, most of the writers fail to specify which of many feminisms has been taken on board. It is disquieting how consensual and self-enclosed is this voice in recent feminist writing, perhaps indicative of some refusal of pain or suffering, for fear of being seen to, once again, occupy the dreaded space of the repudiated angry feminist, or for fear of endorsing victim-oriented feminism. To sum up, just because feminism finds a place in the everyday vocabularies of popular culture, does not mean that the ideological force of these forms is somehow depleted, or that the power relations inscribed within these modes of entertainment melt away. They do not suddenly become simply the bearers of innocuous escapist pleasures for women. And just because women readers and audiences, as already multiply positioned subjects, (i.e. well-educated and politically informed citizens etc.) are thereby understood to be endowed with 
'active' capacities of judgement, discrimination, and also critique, this does not mean that popular entertainment is somehow robbed of its powers, becoming shrunken in influence, or that it is without an ability to produce even more self-reflexive and highly-activated subject positions for women, so as to in fact re-vitalize existing patriarchal relations of power and domination by securing anew the consent of women to existing social and political arrangements. To ignore the force field within which these cultural forms circulate is to abandon the ethical and the political underpinning of feminist media and cultural studies scholarship.

\section{Pole dancing for pre-teens?}

There is an increasingly visible phenomenon in contemporary culture which operates as a deliberate provocation to that terrain imagined to be feminist. Ros Gill (2003) describes seeing young women wearing T-shirts with the words 'Unbelievable Knockers' across the front. This is not the place to embark on a feminist discussion of the seeming mainstreaming of soft pornography in the public domain, though such a debate is also long overdue. The point here is that Gill's T-shirt invokes the language of tabloid newspapers like The Sun whose journalists have enjoyed demonizing feminism and its supposedly anti-sex and anti-pornography agenda by subjecting, for example, feminist critics of the newspaper like the member of parliament and former government minister Clare Short to public humiliation about her own body size and ridiculing her for her feminist views. The taking up of such T-shirts by young women themselves, is to side with The Sun's defence of its daily nude models on the basis of well endowed young women being proud of their bodies and happy to be well paid for displaying them on the Page Three slot. Even though very few feminist scholars come near to occupying the position of the puritanical anti-sex position of Andrea Dworkin, the wearing of the words 'unbelievable knockers' (typically associated with young men's talk) suggests a denunciation of feminism on the part of the young woman. Culturally, then, the young woman is leant upon to show that she is 'up for it' by distancing herself from the now outdated politics of the women's movement. The same applies to the popularity of lap dancing clubs and to the sale of pole dancing equipment for use at home in the ground floor of Selfridges store in Oxford Street London (Autumn 2004) in the area given over to teenage and preteenage fashion. My intention then in this section is to provide a brief and schematic overview of how a consumer ethic is being addressed to young women with unprecedented force, by means of mobilizing feminine pleasures and inscribing these with a sprinkling of selective, even parent-friendly, feminist values. The young woman is either congratulated for having achieved parity with her male counterparts on the basis of unspecified ('girl power') 
activity, or else she is encouraged to take further action to achieve this goal. By these means, and through this address, consumer culture seeks to triumphantly supplant the functions of the state (education and family) and position itself as the site of truth in regard to what it is to be a young woman today and to be recognized as such.

There has been a sea change in the field of magazines for young, pre-teen girls. In the light of what has been said so far, it may come as no surprise to the reader of this article, that magazines like Bliss and Sugar imagine a very young female consumer into being by, among other things, bestowing on objects of adult or teenage female beautification (thong-style underwear, bikinis, beads, bracelets, body lotion, lipstick), the qualities of children's much loved toys. Thus in some pages furry animals sit alongside pink and glittery nail polish. ${ }^{6}$ With stories and narratives disappeared, the pages are full of fashion spreads and pages of information on fashion related items, as well as on celebrity gossip, pop music, boy bands and girl stars to emulate. As Miller and Rose (1997) argue, forms like these activate the subject by mobilizing her as a consumer; she is called upon to play a key role in deciding what she likes and what suits her such that she participates 'in the world of goods' and comes to recognize herself and be recognized by others by means of this 'political economy of subjectification'. The intimate address, as well as the appeal to emotions, generate new desires and makes then 'thinkable'. The magazines also produce sexuality as both thinkable and recognizable through fashion items such as crop tops, thongs, low-rider jeans, tiny bikinis, and provocative T-shirts, which occasionally gives rise to moral panic by concerned adults (parents, teachers, politicians, journalists).

Cook and Kaiser (2004) point out that anxieties about precocious female sexuality have a long history as mechanisms of social regulation. Of course they are right in this respect but given that the attention in their article is to the increasingly young age at which children, especially girls, are gender differentiated as consumers, one might ask, is it enough to merely historicize such anxieties and to then to go on to explain that in commercial sites such as these young women find space for experimenting with identity? 'Girls may have little control over media representations, but they do exercise agency in the representations they create in the daily process of contemplating and dressing their bodies' (Cook \& Kaiser 2004, p. 206). This is the cultural studies mantra beloved of feminist scholars which is as I have argued, now in need of revision, not least because there has been a consistent failure to acknowledge the complex array of factors at play in this address to very young girls. This style of consumer culture mobilizes children to an ethic of gendered individualization which is competitive, self-seeking, and based on an ethic which seeks instant gratification through access to the world of goods. This in turn comprises the primary regime of truth for very young women, as other social institutions lose their importance. Such a transition, wherein consumer 
culture takes upon itself this role as champion of girls' rights and provider of the wherewithal which permits girls the quest for self-identity, is surely a key question for feminist scholars today. It is by these means that the category of child finds itself increasingly replaced by that of girl. Each of these categories carries the weight of institutional and juridical power, but this new girl is more the offspring of de-regulated consumer culture and of the private corporations than of the older powers of state. We might ask, what price does she pay for such seductive freedoms as those made available by the world of goods and products? ${ }^{7}$ The absence of feminist theorizing on these issues permits a new kind of moralism to go unchallenged. This moral majority discourse on occasion actually blames feminism for these consumer-led sexual freedoms. It is these conservative positions which are now most visible, since feminist media and cultural studies, as I have already explained, has seemingly suspended its critique of consumer culture. And yet the hyper-visibility of preteen girls as the ideal subjects of feminine consumption marks out the contours of new modalities of gender performativity now routinely required of young girls, as a condition of their wider intelligibility, so that they can in effect count as girls.

Sarah Banet-Weiser (2004) provides the most persuasive and illuminating account of (and defence of) Girl Power ideology transposed into Nickelodeon, the mainstream US television channel for children. Her argument is that this kind of commodity feminism 'powerfully demonstrates the contradictions or tensions that structure Third Wave feminist politics, especially for young girls' (Banet-Weiser 2004, p. 120). Banet-Weiser engages in detail both with the various waves of feminist politics (less so with feminist theory) and with the narrative elements of two girl-based television drama series shown on Nickelodeon, Clarissa Explains It All and As Told By Ginger. In addition she pinpoints the presence of 'activist' feminist journalists behind the scenes in these programmes including the news slots which also foregrounds girls' issues such as 'The Fight to Fit In' and 'The Body Trap'. Banet-Weiser mentions the Girl Power seminar hosted at Nickelodeon, and the channel's subsequent reputation as a 'risk taker' and 'champion for girls in television'. These developments also mean that the channel is 'a significant producer of girl power culture - especially since Nickelodeon is one of the most influential producers of children's programming and media in the U.S., and it attracts a large audience of pre-adolescent and adolescent girls' (Banet-Weiser 2004, p. 121). Banet-Weiser argues that there is a convergence of interests here between Third Wave feminism which 'embraces commercial media and enthusiastically celebrates the power that comes with it' and the programmes which now feature assertive and intelligent girls like Clarissa. She also - in a move I myself have also made in the past - defends the Third Wave girls on the basis of the proliferation of feminisms, and against the dogmatism of the Second Wave feminists with their claims to universalism and their interest in 
controlling the boundaries of the women's movement. ${ }^{8}$ However, she continues 'In fact, we have arrived at a point where much of (liberal) feminism is part of mainstream media culture: that this is not a problem could be taken as a measure of what Second Wave feminism has accomplished' (Banet-Weiser 2004, p. 122).

My argument with Banet-Weiser here is with her suggestion that such incorporation is 'not a problem'. For it occurs in a context where only liberal feminism finds itself palatable enough to be taken on board, and when this does occur, as I have pointed out here, it is within a framework of an exponential growth in girl consumerism, which is, surely, just as much a rationale for these modalities of inclusion as the acclaim for social responsibility and risk taking? In addition, 'Third Wave' is here an umbrella for a kind of girl power which celebrates media visibility, which Banet-Weiser associates with riotgrrl subcultures, and which as I understand them do quite the opposite (Harris 2004). Maybe we need to unpack further these various categories - Third Wave, riotgrrl, 'commodity feminism'. So far there have been few questions asked about the class and ethnic composition of the Third Wave. To whom do these Nickelodeon or Nike versions of commodity feminism reach? BanetWeiser concludes by drawing on the seeming ubiquity of the contradictions facing young women 'about the individual pleasures of consumption and the social responsibilities of solidarity' implying that these kinds of quality television programmes primarily engage with the former without completely eschewing the latter (Banet-Weiser 2004, p. 137). However, local instances of progressive narratives on mainstream television like these echo the case I and Janice Winship made for occasionally liberating moments in the world of girls' magazines in the mid to late 1980s. Does Banet-Weiser then need to augment her account of changes like these with fuller understanding of the limits of feminist input in commercial media, including their labour processes, and also the wider environment of prime-time advertising (and its gendered content) which provides the financial underpinning for programmes such as these?

In what is indeed a thoughtful and highly informative account BanetWeiser concludes her article by proposing an analysis of Third Wave feminism on its own terms and without the ghost of socialist-feminism past, the 'nostalgic golden age of feminism in the 1970s' (Banet-Weiser 2004, p. 137). Indeed this comment describes the parameters of my concerns here but from the opposite side of the post-feminist fence. Refuting the vocabulary of nostalgia, my interest is in showing how such associations of nostalgia are generated so as to invalidate in advance other modalities of inter-generational connection, and also how this works to undo and ensure there is no return of a feminism which is predicated on sustained social and cultural analysis and critique, a critique which can be attentive to the means by which women, and especially young women, must now be drawn into, as 'active subjects' the fields of work, employment and consumption. To sum up, my concerns here 
have therefore been to re-activate the terms of feminist critiques of consumer culture so as to address the increasingly powerful role played by these forces for young women, for girls, and also for pre-teen girls. Without such a renewed focus, there is the danger of both lapsing into complicitous complacency and merely adding a feminist voice to various moral panics. This newly critical stance I am advocating would also entail the resuscitation and re-conceptualization of feminist anti-capitalism. It has also been my intention to suggest that this terrain of study badly needs the theoretical input found in the writings of Foucault and Butler among others. Our field of feminist media and cultural studies is fatally weakened without the presence of psychoanalytical thinking, and it is politically compromised, to say the least, in the absence of a vocabulary which confronts the way in which new forms of constraint and regulation emerge through a seeming proliferation of female 'freedoms' (made available, however, to subjects limited in terms of race and class) the appeal of which is seemingly enhanced by the presence of values borrowed from feminist discourse. Thus we need to be fully attentive to the instrumentalization of feminism as a source of innovation and dynamism for consumer culture.

\section{Acknowledgements}

A short version of this paper was first presented at HM Treasury as part of the 'Cultures of Consumption' AHRC Programme. Thanks to Frank Trentmann for inviting me.

\section{Notes}

1 See Goldman (1992).

2 This extending of the academic discourse of feminist cultural studies into other non-academic fields such as popular music, magazines, television and radio was at the time considered worthwhile first as a means of having an impact in effecting cultural policy, and second for its boundary-breaking possibilities: as a strategy for enabling cross-institutional dialogue. However, this practice has been widely misunderstood as a kind of capitulation to the values of dominant culture, a populist gesture marking out the abandonment of critique; the opposite of Adorno's famous 'nicht mitmachen' position.

3 Marie-Claire magazine is a good example: for the short period in 2000 when it was edited by Liz Jones, it adopted an aggressive stance on the tyranny of slimness, but this stance was dropped as circulation fell and the editor forced to resign.

4 For an account of 'complicitous critique' see Hutcheon (2002). 
5 Closer textual analysis than I can carry out here would be needed to dissect the basis of this shudder; suffice it to say it was somehow inscribed within the persona, and the not unattractive appearance of the temporary girlfriend. For a fuller discussion of pre-teen marketing and retail culture see Russell and Tyler (2002).

7 The Guardian newspaper reported on the 28 November 2005 a huge rise in self-harming behaviour among young girls in the UK. The author of the study blames the ethos of instant gratification along with the pressures to be perfect promulgated by media and consumer culture.

Banet-Weiser (2004) refers to the oft-quoted comment from Second Wave feminist Susan Brownmiller that these young women of the Third Wave are 'not movement people'.

\section{References}

Adorno, T. (1991) The Culture Industry: Selected Essays on Mass Culture, ed. J. M. Bernstein, New York, Routledge.

Althusser, L. (1971) 'Ideology and ideological state apparatuses', in Lenin and Philosophy and Other Essays, New York, Monthly Review Press.

Akass, K. \& McCabe, J. (2004) Reading Sex and the City, London, I.B Tauris.

Arthurs, J. (2004) Television and Sexuality, Open University Press, Maidenhead.

Banet-Weiser, S. (2004) 'Girls Rule! Gender, feminism and Nickelodeon', Critical Studies in Media Communication, vol. 21, no. 2, pp. 119-139.

Brunsdon, C. (1997) Screen Tastes: Soap Opera to Satellite Dishes, London, Routledge.

Brunsdon, C. (2005) 'Feminism, postfeminism, Martha, Martha and Nigella, Cinema Journal, vol. 44, no. 2, pp. 110-116.

Brunsdon, C., et al (eds) (1997) Feminist Television Criticism: A Reader, Oxford, Oxford University Press.

Butler, J. (1990) Gender Trouble, New York, Routledge.

Butler, J. (2005) Giving an Account of Oneself, New York, Fordham University Press.

Cook, D. \& Kaiser, S. (2004) 'Betwixt and between', Journal of Consumer Culture, vol. 4, no. 2, pp. 203-229.

Dow, B. (1996) Prime-Time Feminism, Philadelphia, PA, University of Pennsylvania Press.

Gerhard, J. (2005) 'Sex and the City: Carrie Bradshaw's queer postfeminism', Feminist Media Studies, vol. 5, no. 1, pp. 37-51.

Gill, R. (2003) 'From sexual objectification to sexual subjectification', Feminist Media Studies, vol. 3, no. 1, pp. 100-106.

Gill, R. (2006) Gender and the Media, Cambridge, Polity Press.

Goldman, R. (1992) Reading Ads Socially, New York, Routledge.

Harris, A. (2004) Future Girl, London, Routledge.

Hutcheon, L. (2002) The Politics of Postmodernism, 2nd edn, New York, Routledge. 
Jermyn, D. (2004) 'In love with Sarah Jessica Parker; celebrating female fandom and friendship in Sex in the City', in Reading Sex and the City, eds K. Akass \& J. McCabe, London, I.B Tauris, pp. 201-219.

Lotz, A. (2001) 'Postfeminist television criticism', Feminist Media Studies, vol. 1, no. 1 , pp. 105-121.

McGuigan, J. (1992) Cultural Populism, London, Routledge.

McRobbie, A. (1999) In the Culture Society, London, Routledge.

McRobbie, A. (2004) 'Post feminism and popular culture', Feminist Media Studies, vol. 4, no. 2, pp. 255-265.

Merck, M. (2004) 'Sexuality in the City', in Reading Sex and the City, eds K. Akass \& J. McCabe, London: I.B Tauris, pp. 48-65.

Miller, P. \& Rose, N. (1997) 'Mobilizing the consumer', Theory, Culture and Society, vol. 14, no. 1, pp. 1-35.

Moseley, R. \& Read, J. (2002) “"Having It Ally”; popular television (post-) feminism', Feminist Media Studies, vol. 2, no. 2, pp. 231-251.

Nancy, J.-L. (2000) La Creation du Monde ou Mondialisation, Paris, Galilee.

Russell, R. \& Tyler, M. (2002) 'Thank heavens for little girls: "Girl Heaven" and the commercial context of feminine childhood', Sociology, vol. 36, no. 3, pp. 619-637.

Tasker, Y. \& Negra, D. (eds) (2005) 'In focus: postfeminism and contemporary media studies', Cinema Journal, vol. 44, no. 2, pp. 107-110.

Tasker, Y. \& Negra, D. (eds) (2006) Interrogating Post-feminism, Durham, NC, Duke University Press.

Winship, J. (1987) Inside Women's Magazines, London, Pandora.

Zeiger, S. (2004) 'Sex and the citizen in Sex in the City's New York', in Reading Sex and the City, eds K. Akass \& J. McCabe, London, I.B Tauris, pp. 96-115.

Žižek, S. (2004) "The ongoing "Soft Revolution", Critical Inquiry, vol. 30, pp. 292-323. 